\title{
Morphological development of larvae and juveniles of Prochilodus argenteus
}

\author{
Irũ Menezes Guimarães ${ }^{1 *}$ Vinícius Augusto Dias Filho $^{2}$ Ana Helena Gomes da Silva ${ }^{1}$ \\ Rafael Silva Santos ${ }^{1}$ William Severi ${ }^{3}$
}

${ }^{1}$ Centro Integrado de Recursos Pesqueiros e Aquicultura de Betume, Companhia de Desenvolvimento dos Vales do São Francisco e do Parnaíba (Codevasf), Rodovia SE-120, km 10, 49980-000, Neópolis, SE, Brasil. E-mail: iruguimaraes@gmail.com. "Corresponding author.

${ }^{2}$ Centro Integrado de Recursos Pesqueiros e Aquicultura de Itiúba, Companhia de Desenvolvimento dos Vales do São Francisco e do Parnaíba (Codevasf), Porto Real do Colégio, AL, Brasil.

${ }^{3}$ Departamento de Pesca e Aquicultura, Universidade Federal Rural de Pernambuco (UFRPE), Recife, PE, Brasil.

ABSTRACT: Prochilodus argenteus is an endemic fish species from the São Francisco River basin that is of high economic and environmental importance. The present study aimed to contribute with information to the taxonomic identification of larvae and juveniles of this species. Larvae, obtained from induced spawning of wild animals, were reared in ponds. Individuals were collected daily and classified into larval stages or juvenile phase. Morphological descriptions and morphometric measurements were performed, together with a piece wise linear regression analysis of the body proportions throughout the development process. Individuals in the preflexion stage had a standard length (SL) of 4.48 to $6.64 \mathrm{~mm}$, long to moderate body (BH/SL), small to moderate head (HL/SL), and a small to moderate eve (ED/HL). In the flexion stage, the SL varied from 6.60 to $11.00 \mathrm{~mm}$, long to moderate body, moderate head, and small to moderate eye. Larvae in the postflexion stage presented SL of 10.54-19.93mm, moderate body, moderate to big head and small eye. The juvenile phase included specimens with a SL of 18.27 to $42.21 \mathrm{~mm}$ which presented a moderate to high body, big head and small to moderate eye. Regression analysis showed significant moments of change in rate of increase of the body proportions, presenting a change in the growth pattern from allometry to isometry during the early development.

Key words: curimatã, early development, morphometry, São Francisco River.

\section{Desenvolvimento morfológico de larvas e jovens de Prochilodus argenteus}

RESUMO: Prochilodus argenteus é uma espécie de peixe endêmica da bacia do Rio São Francisco, com importância econômica e ecológica para a região. O objetivo deste trabalho foi contribuir com informações para a identificação taxonômica de larvas ejovens da espécie. As larvas foram obtidas através de reprodução induzida de animais selvagens e cultivadas em viveiros. Os peixes foram coletados diariamente e classificados nos estágios larvais e fase juvenil. Foi realizada a descrição morfológica e medidas morfométricas, além de uma análise de regressão linear segmentada das proporções corporais ao longo do desenvolvimento. O estágio de pré-flexão apresentou individuos com comprimento padrão (CP) de 4,48 a 6,64mm, corpo longo a moderado (AC/CP), cabeça pequena a moderada (CC/CP) e olho pequeno a moderado (DO/CC). Em flexão, o CP variou de 6,60 a $11,00 \mathrm{~mm}$ com corpo longo a moderado, cabeça moderada e olho pequeno a moderado. No estágio de pós-flexão, as larvas apresentaram CP de 10,54 a 19,93mm, corpo moderado, cabeça moderada a grande e olho pequeno. A fase juvenil compreendeu individuos de 18,27 a 42,21mm CP, corpo moderado a alto, cabeça grande e olho pequeno a moderado. As análises de regressão evidenciaram os momentos significativos de mudança no ritmo de incremento das proporções corporais, demonstrando uma mudança no padrão de crescimento de alométrico para isométrico durante o desenvolvimento inicial. Palavras-chave: curimatã, desenvolvimento inicial, morfometria, rio São Francisco.

\section{INTRODUCTION}

Fishes of Prochilodus genus, popularly known as curimatã, have a migratory behavior, are widely distributed in South American rivers, and represent an important fishing resource. This genus includes thirteen species of which ten are present in the Brazilian basins. For instance, the São Francisco River Basin is the natural habitat of the species $\boldsymbol{P}$. argenteus, $\boldsymbol{P}$. costatus, $\boldsymbol{P}$. vimboides, and $\boldsymbol{P}$. brevis (CASTRO $\&$ VARI, 2003). Although Prochilodus argenteus is considered an endemic species of the São Francisco River Basin it has been taken to other Brazilian basins (Northeast) through governmental fish stocking programs (CASTRO \& VARI, 2004). In the Lower São
Francisco River region, this species has a substantial commercial value due to its participation in artisanal fisheries (SOARES et al., 2011) and subsistence aquaculture (RIBEIRO-NETO et al., 2016). On the face of its economic and ecological importance, the species was included in the recovery program of São Francisco River fish fauna implemented by government institutions. The identification process of $\boldsymbol{P}$. argenteus in the ichthyoplankton fauna can reveal important information about breeding areas and feeding and growth routines essential for the management and conservation of species. In the case of the genus Prochilodus, it is relatively easy to find information on its larval development in published literature, from which were reported information about eight among 
the thirteen recorded species (CAVICCHIOLI \& LEONHARDT, 1993; LEÓN et al., 1993; NAKATANI et al., 2001; ARIAS-GALLO et al., 2010; ABDO et al., 2015; SOUZA et al., 2015). However, the identification of Prochilodus larvae and a proper separation of their species are hampered by overlapping parameters (morphometric and meristic) due to the evolutionary proximity between species of this genus (CASTRO $\&$ VARI, 2004). Thus, the present study aimed to provide information for the taxonomic identification of larvae and juveniles of $\boldsymbol{P}$. argenteus through the morphological and morphometric characterization of their early development in captivity. This could also enable differentiation from their congeners of the São Francisco River Basin.

\section{MATERIALS AND METHODS}

This study was conducted using individuals of $\boldsymbol{P}$. argenteus that hatched in the laboratory by means of hormonal induction of wild broodstock from the Lower São Francisco river (Porto Real do Colégio-AL, $10^{\circ} 12^{\prime} 1.93^{\prime \prime} \mathrm{S}$ and $036^{\circ} 47^{\prime} 30.32^{\prime \prime} \mathrm{W}$ ) and were kept in ponds in the Center of Reference for Aquaculture and Fisheries Resources of São Francisco (CERAQUA/ CODEVASF). Two days post-hatch (DPH) larvae, already presenting open mouths, were transferred from the nursery to a grow-out pond $\left(2000 \mathrm{~m}^{2}\right)$ and were retained there for 44 days. Individuals were captured daily and fixed in 4\% neutralized formalin. Each individual was morphologically examined and photographed with a digital camera (5.1 MP) attached to a light microscope. The Image J software was used for image capturing and morphological measuring $(0.001 \mathrm{~mm}$ accuracy $)$ and the results were presented using an accuracy of $0.01 \mathrm{~mm}$. Fish were individually weighed on an analytical balance with an accuracy of $0.0001 \mathrm{~g}$.

Individuals examined were classified into larval stages of development as preflexion, flexion, and postflexion, and juvenile phase according to the flexion degree of the notochord and caudal fin development (KENDALL et al., 1984). In addition, the standard length (SL), body height (BH), head length (HL), predorsal (PDD), pre-pectoral (PPD), pre-pelvic (PPLD), and pre-anal (PAD) fin distances, as well as the eye diameter (ED) and upper maxillary length (UML), were measured.

Calculations of $\mathrm{BH} / \mathrm{SL}, \mathrm{HL} / \mathrm{SL}, \mathrm{PDD} / \mathrm{SL}$, $\mathrm{PPD} / \mathrm{SL}, \mathrm{PPLD} / \mathrm{SL}, \mathrm{PAD} / \mathrm{SL}, \mathrm{ED} / \mathrm{HL}$, and UML/ HL were performed. The ratio $\mathrm{BH} / \mathrm{SL}, \mathrm{HL} / \mathrm{SL}$, and ED/HL were respectively used to classify the body, head and eye sizes of the individuals according to LEIS \& TRNSKI (1989). The body proportions measurements were correlated with SL and HL and analyzed through the piecewise linear regression model $Y=\beta 0+\beta 1 X+\beta 2(X-b p)(X>b p)+\varepsilon$ in order to calculate the models break-points $(b p)$ and estimate the shift instants $\left(X_{b p}\right)$ in the ratio increment on the morphometric measurements (body proportions) related to the initial development of the fish.

\section{RESULTS}

A total of 233 individuals were analyzed in this study, of which 46 were larvae in the preflexion stage, 31 in the flexion stage, 102 in the postflexion stage, and 49 in the juvenile phase. The mean water temperature was $29.3^{\circ} \mathrm{C}$ during the nursery period and $30.8^{\circ} \mathrm{C}$ during the grow-out period. The means and amplitudes of morphometric and meristic variables of each stage of development are presented in table 1 .

Preflexion stage larvae (Figures $1 \mathrm{~A}$ and B) were between 2 and $5 \mathrm{DPH}$, with SL from 4.48 to $6.64 \mathrm{~mm}$ and a weight of $0.0009-0.0028 \mathrm{~g}$. Their body was long to moderate $(12.99-20.75 \%$ SL), with small to moderate head (19.51-27.61\% SL) and small to moderate fully pigmented eye (21.82-29.07\% HL). They presented open mouth in a terminal position and presence of exogenous food in the stomach and in the intestine. In this period, the embryonic finfold involves the body of the larva from the dorsal to the ventral region. Caudal, dorsal, anal, and pelvic fins are not visible. The gas bladder is pigmented and clearly visible in the upper portion of the abdominal cavity. At the beginning of the preflexion stage, dendritic chromatophores are present in the ventral region, from the posterior region of the head to the anus and in the posterior lateral and superior region of the head. During the development the pigmentation intensifies on the dorsal area and, later, on the body sides. At the end of the preflexion stage, chromatophores emerge in the area underneath the terminal portion of the notochord.

Flexion stage larvae (Figures $1 \mathrm{C}$ and D) were between 5 and $6 \mathrm{DPH}$, with SL varying from 6.60 to $11.00 \mathrm{~mm}$ and weight varying from 0.0025 to $0.0225 \mathrm{~g}$. Their body varied from long to moderate $(16.68-25.71 \% \mathrm{SL})$, the head was moderate $(24.75-32.03 \% \mathrm{SL})$ and the eye was small to moderate (20.63-28.51\% HL). At this stage, the initial formation of rays (pterygiophores) occurs in the order of caudal, dorsal, and anal fins. The embryonic finfold is still present but it is shorter than in the preflexion stage and mainly restricted to the ventral region. Dendritic and punctate pigmented chromatophores are present on the body sides, including the lips. At the end of this stage, 
Table 1 - Morphological variables of Prochilodus argenteus (Spix \& Agassiz, 1829) at larval stages and initial juveniles reared in ponds from the $2^{\text {nd }}$ to the $44^{\text {th }}$ days post-hatch (n, number of individuals; $\bar{X}$, mean; SD, standard deviation; $C F$, caudal fin; $D F$, dorsal fin; $\mathrm{AF}$, anal fin; PLF, pelvic fin and PF, pectoral fin).

\begin{tabular}{|c|c|c|c|c|c|c|c|c|}
\hline \multirow{3}{*}{$\begin{array}{l}\text { Stage Phase } \\
\text { Measure } \\
(\mathrm{mm})\end{array}$} & \multicolumn{6}{|c|}{---------------------------------------------------Larvae----------------------------------------------------- } & \multicolumn{2}{|c|}{-------Juvenile (n=49)------- } \\
\hline & \multicolumn{2}{|c|}{------Preflexion $(\mathrm{n}=46)------$} & \multicolumn{2}{|c|}{----Flexion $(n=31)$} & \multicolumn{2}{|c|}{----Postflexion $(n=102)-----$} & \multirow[b]{2}{*}{$\bar{X} \pm \mathrm{SD}$} & \multirow[b]{2}{*}{ Range } \\
\hline & $\bar{X} \pm \mathrm{SD}$ & Range & $\bar{X} \pm \mathrm{SD}$ & Range & $\bar{X} \pm \mathrm{SD}$ & Range & & \\
\hline SL & $5.57 \pm 0.49$ & $4.84-6.64$ & $8.55 \pm 1.19$ & $6.60-11.00$ & $13.95 \pm 2.00$ & $10.54-19.93$ & $25.19 \pm 5.27$ & $18.27-42.21$ \\
\hline HL & $1.31 \pm 0.20$ & $1.06-1.77$ & $2.38 \pm 0.43$ & $1.63-3.22$ & $5.13 \pm 1.00$ & $3.37-7.99$ & $9.90 \pm 1.93$ & $7.10-15.70$ \\
\hline $\mathrm{BH}$ & $0.95 \pm 0.15$ & $0.67-1.29$ & $1.80 \pm 0.42$ & $1.20-2.74$ & $4.41 \pm 1.11$ & $2.80-7.57$ & $9.87 \pm 2.36$ & $6.60-17.53$ \\
\hline PPD & $1.30 \pm 0.19$ & $1.06-1.76$ & $2.32 \pm 0.39$ & $1.65-3.12$ & $4.73 \pm 0.80$ & $3.18-6.76$ & $8.39 \pm 1.66$ & $6.17-13.44$ \\
\hline PDD & - & - & $4.06 \pm 0.45$ & $3.28-4.86$ & $6.80 \pm 1.12$ & $5.00-9.86$ & $12.92 \pm 2.65$ & $9.12-20.59$ \\
\hline PAD & - & - & $6.38 \pm 0.99$ & $4.71-8.53$ & $11.03 \pm 1.69$ & $8.42-15.94$ & $20.74 \pm 4.42$ & $14.78-35.06$ \\
\hline PPLD & - & - & - & - & $7.73 \pm 1.36$ & $5.64-11.47$ & $14.85 \pm 3.00$ & $10.86-24.51$ \\
\hline ED & $0.33 \pm 0.04$ & $0.26-0.41$ & $0.54 \pm 0.11$ & $0.39-0.74$ & $1.24 \pm 0.33$ & $0.76-2.21$ & $2.69 \pm 0.50$ & $1.78-3.70$ \\
\hline UML & $0.35 \pm 0.06$ & $0.25-0.50$ & $0.60 \pm 0.09$ & $0.44-0.76$ & $1.13 \pm 0.31$ & $0.67-2.02$ & $2.28 \pm 0.57$ & $1.39-4.08$ \\
\hline \multicolumn{9}{|c|}{ - } \\
\hline $\mathrm{ED} / \mathrm{HL}$ & $25.77 \pm 1.52$ & $21.82-29.07$ & $22.79 \pm 1.75$ & $20.63-28.51$ & $22.79 \pm 1.53$ & $20.20-26.89$ & $27.27 \pm 2.38$ & $22.67-32.63$ \\
\hline $\mathrm{UML} / \mathrm{HL}$ & $26.77 \pm 2.64$ & $20.85-34.63$ & $25.69 \pm 3.04$ & $18.81-30.78$ & $21.37 \pm 1.81$ & $17.93-26.14$ & $22.85 \pm 2.27$ & $17.17-27.83$ \\
\hline HL/SL & $23.38 \pm 1.87$ & $19.51-27.61$ & $27.75 \pm 1.71$ & $24.75-32.03$ & $35.21 \pm 1.85$ & $31.38-38.52$ & $39.43 \pm 1.51$ & $36.72-43.65$ \\
\hline $\mathrm{BH} / \mathrm{SL}$ & $16.97 \pm 1.69$ & $12.99-20.75$ & $20.79 \pm 2.30$ & $16.68-25.71$ & $29.21 \pm 2.15$ & $25.36-36.32$ & $38.98 \pm 1.45$ & $35.99-41.97$ \\
\hline $\mathrm{PPD} / \mathrm{SL}$ & $23.33 \pm 1.82$ & $19.51-27.61$ & $27.06 \pm 1.45$ & $24.53-30.45$ & $33.13 \pm 1.83$ & $29.27-36.84$ & $33.39 \pm 1.62$ & $30.46-38.62$ \\
\hline $\mathrm{PDD} / \mathrm{SL}$ & - & - & $47.11 \pm 2.03$ & $43.00-50.84$ & $47.79 \pm 1.37$ & $45.14-52.35$ & $51.32 \pm 1.34$ & $48.35-54.66$ \\
\hline $\mathrm{PAD} / \mathrm{SL}$ & - & - & $74.51 \pm 2.31$ & $69.32-78.80$ & $78.83 \pm 1.81$ & $75.88-84.19$ & $82.27 \pm 1.06$ & $79.23-84.64$ \\
\hline PPLD/SL & - & - & - & - & $53.97 \pm 1.30$ & $51.04-58.58$ & $59.07 \pm 1.29$ & $57.17-62.14$ \\
\hline \multicolumn{9}{|c|}{ - } \\
\hline $\mathrm{CF}$ & - & - & - & $6-19$ & - & $18-19$ & - & 19 \\
\hline DF & - & - & - & $6-8$ & - & $9-11$ & - & 11 \\
\hline $\mathrm{AF}$ & - & - & - & $2-6$ & - & $7-11$ & - & 11 \\
\hline PLF & - & - & - & - & - & $0-9$ & - & $8-9$ \\
\hline $\mathrm{PF}$ & - & - & - & - & - & $0-14$ & - & 15 \\
\hline
\end{tabular}

pigmentation is clearly observed between the rays of caudal, anal, and dorsal fins.

Postflexion stage larvae (Figures $1 \mathrm{E}, \mathrm{F}$, and G) were between 7 and $40 \mathrm{DPH}$, with SL ranging from 10.54 to $19.93 \mathrm{~mm}$ and weight varying from 0.0178 to $0.2810 \mathrm{~g}$. The body was moderate $(25.36-36.32 \%$ SL), with moderate to large head (31.38-38.52\% SL) and small to moderate eye (20.20-26.89\% HL). During this period, a vestigial finfold is present in the dorsal and ventral areas of the caudal peduncle, but it is well developed in the ventral region, between the anus and head. Appearance of the pelvic fin button followed by the development of its rays occur at the end of this stage, together with the appearance of the adipose fin, scales and discrete transverse stripes along the body sides because of agglomeration of chromatophores.

The juvenile phase (Figure $1 \mathrm{H}$ ) included individuals with $18.27-42.21 \mathrm{~mm}$ SL, body weight from 0.1990 to $2.4380 \mathrm{~g}$, belonging to the period comprised between 20 and $44 \mathrm{DPH}$. The body varied from moderate to high (35.99-41.97\% SL) and the head was large $(36.72-43.65 \%$ SL) with a small to moderate eye (22.67-32.63\% HL). During this period, all fins are fully formed, with absence of the embryonic finfold. Transverse stripes are visible throughout the body, being more evident above the lateral line.

Models originated by piecewise linear regressions presented significant instants of change in the rate of increase considering the body proportions relative to $\mathrm{SL}$ and $\mathrm{HL}$ (Figure 2). The $\mathrm{BH} / \mathrm{SL}$ proportion increased from the preflexion stage to the transition between the postflexion stage and the juvenile for individuals with $\mathrm{SL}<17.84 \mathrm{~mm}$, followed by a stabilization in larger individuals. The HL/SL proportion presented a similar pattern, differing only in the size at which the change occurs, this being at the end of the postflexion stage when the SL was $15.90 \mathrm{~mm}$.

All the proportions of pre-fin distances relative to SL had an initial increase during $\boldsymbol{P}$. argenteus development, remaining constant afterwards. The PPD/ SL proportion remained constant for individuals with SL $>14.47 \mathrm{~mm}$ and throughout the postflexion stage. The 


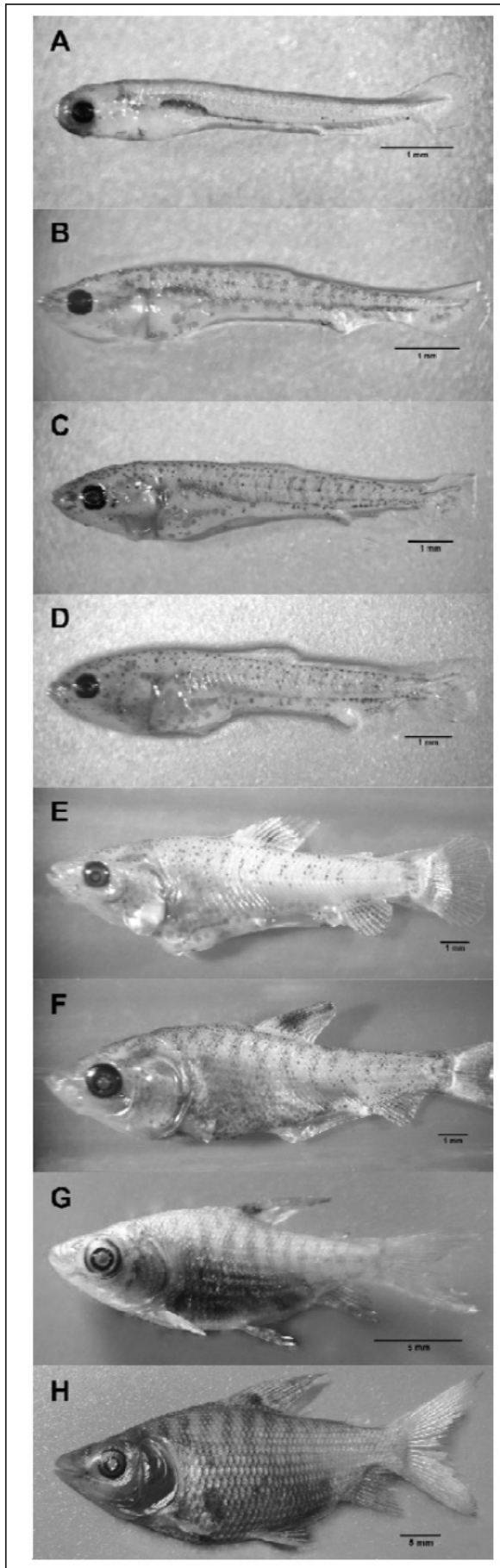

Figure 1 - Initial development of Prochilodus argenteus (Spix \& Agassiz, 1829) grown in experimental conditions from the $2^{\text {nd }}$ to the $44^{\text {th }}$ days posthatch. 1A: initial preflexion stage, 1B: late preflexion stage, $1 \mathrm{C}$ : initial flexion stage, 1D: flexion stage, 1E: initial postflexion stage, $1 \mathrm{~F}$ : postflexion stage, 1G: late postflexion stage and $1 \mathrm{H}$ : early juvenile phase.
PPLD/SL proportion stabilized amid the postflexion stage and the juvenile phase in individuals with SL $>18.62 \mathrm{~mm}$. The PAD/SL and PDD/SL proportions showed a tendency to the stabilization in the juvenile phase and in individuals measuring 20.47 and $21.74 \mathrm{~mm}$ SL, respectively.

The piecewise linear model of the ED/HL proportion showed a reduction in the body proportion from the preflexion until the beginning of the flexion stage and in individuals with $\mathrm{HL}<2.12 \mathrm{~mm}$, as well as an increase in the subsequent developmental stages. The UML/HL proportion decreased until the early postflexion stage, the larvae having reached $3.81 \mathrm{~mm}$ HL, remaining constant thereafter.

\section{DISCUSSION}

Morphometric and meristic variables of larvae and juveniles of $\boldsymbol{P}$. argenteus obtained from wild broodstock were similar to those reported for other species of Prochilodus (NAKATANI et al., 2001; ARIAS-GALO et al, 2010; SOUZA et al, 2015), which can be explained by the evolutionary proximity between species (CASTRO \& VARI, 2004). Furthermore, the body proportions of $P$. argenteus reported in this study were quite similar to those described in the literature for its congeners from the São Francisco River Basin, namely $\boldsymbol{P}$. costatus, $\boldsymbol{P}$. vimboides, and $\boldsymbol{P}$. brevis (Table 2 ). However, the maximum and minimum values of ED/HL, HL/SL, and $\mathrm{BH} / \mathrm{SL}$ recorded for each larval stage varied between species. Morphometric data showed differences in the average $\mathrm{ED} / \mathrm{HL}$ proportion in the preflexion and postflexion stages and in the BH/SL proportion in the flexion stage between $\boldsymbol{P}$. argenteus and $\boldsymbol{P}$. brevis. The average HL/SL proportion in the postflexion stage was greater in $\boldsymbol{P}$. argenteus than in $\boldsymbol{P}$. vimboides. Formation of fin rays in $\boldsymbol{P}$. argenteus seemed to begin later than in $\boldsymbol{P}$. vimboides since the latter presents rays in the caudal fin already in the preflexion stage. Moreover, in $\boldsymbol{P}$. vimboides, dorsal and anal fins are practically formed at the end of the flexion stage, which was not observed in $\boldsymbol{P}$. argenteus at the same larval stage. Although the paucity of morphological data for larvae of these species hampers an accurate taxonomic identification of all larval stages, the information herein provided serves as discriminators that contribute for the larvae identification process.

The observed morphometric variables of larvae and juveniles of $\boldsymbol{P}$. argenteus from the Lower São Francisco River differed from those recorded by NAKATANI et al. (2001) for this species based on cultured individuals originating from the Upper São Francisco River (Três Marias-MG, 18¹1'59.80"S 

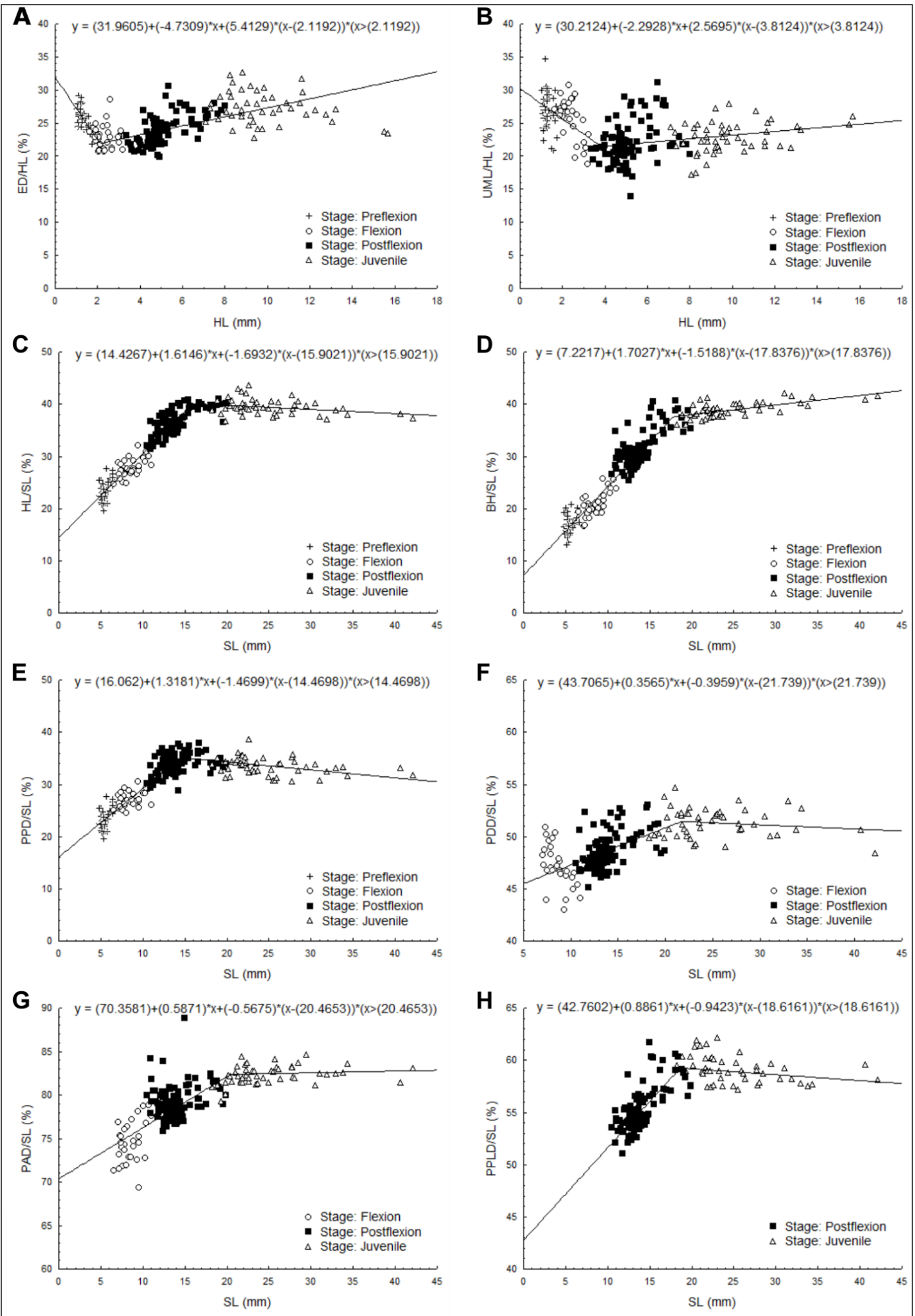

Figure 2 - Piecewise linear regression $Y=\beta 0+\beta 1 X+\beta 2(X-b p)(X>b p)+\varepsilon$ of morphological proportions in the initial development of Prochilodus argenteus. 
Table 2 - Body proportions and meristic data of larvae and juveniles of Prochilodus species occurring in the São Francisco River Basin $(\bar{X}$, mean; SD, standard deviation; CF, caudal fin; DF, dorsal fin; AF, anal fin; PLF, pelvic fin and PF, pectoral fin).

\begin{tabular}{|c|c|c|c|c|c|c|c|c|}
\hline \multirow{3}{*}{ Stage/Phase } & \multicolumn{2}{|c|}{--Prochilodus argenteus-- } & \multicolumn{2}{|c|}{---Prochilodus costatus ${ }^{1}---$} & \multicolumn{2}{|c|}{--Prochilodus vimboides ${ }^{2}--$} & \multicolumn{2}{|c|}{-----Prochilodus brevis ${ }^{1}----$} \\
\hline & $\bar{X} \pm \mathrm{SD}$ & Range & $\bar{X} \pm \mathrm{SD}$ & Range & $\bar{X}$ & Range & $\bar{X} \pm \mathrm{SD}$ & Range \\
\hline & \multicolumn{8}{|c|}{ 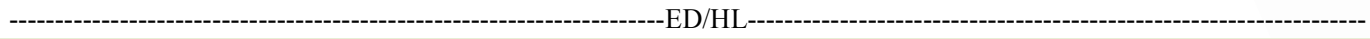 } \\
\hline Preflexion & $25.77 \pm 1.52$ & 21.82-29.07 & $29.73 \pm 2.95$ & $25.98-33.60$ & $25.47 \pm 2.79$ & 22.22-32.46 & $32.24 \pm 3.10$ & $25.15-37.38$ \\
\hline Flexion & $22.79 \pm 1.75$ & 20.63-28.51 & $26.44 \pm 1.59$ & $23.81-28.57$ & $24.81 \pm 2.82$ & $17.91-33.86$ & $25.99 \pm 2.05$ & $23.81-28.63$ \\
\hline Postflexion & $22.79 \pm 1.53$ & $20.20-26.89$ & $26.16 \pm 1.93$ & $18.96-28.22$ & $23.70 \pm 2.44$ & $17.29-27.90$ & $29.03 \pm 2.01$ & $25.06-33.27$ \\
\hline Juvenile & $27.27 \pm 2.38$ & $22.67-32.63$ & - & - & - & - & - & - \\
\hline \multicolumn{9}{|c|}{ 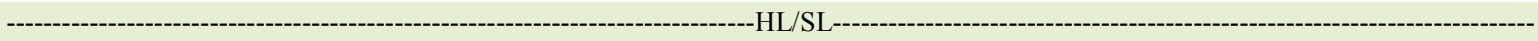 } \\
\hline Preflexion & $23.38 \pm 1.87$ & $19.51-27.61$ & $19.93 \pm 0.94$ & $18.02-22.12$ & $24.90 \pm 2.55$ & $17.94-27.30$ & $19.72 \pm 1.93$ & $17.45-25.38$ \\
\hline Flexion & $27.75 \pm 1.71$ & $24.75-32.03$ & $25.89 \pm 0.95$ & $24.36-27.71$ & $28.41 \pm 2.04$ & $20.52-30.88$ & $27.73 \pm 2.89$ & $24.42-31.62$ \\
\hline Postflexion & $35.21 \pm 1.85$ & $31.38-38.52$ & $33.84 \pm 2.69$ & $29.71-43.04$ & $27.71 \pm 3.68$ & - & $33.72 \pm 1.70$ & $30.03-36.61$ \\
\hline Juvenile & $39.43 \pm 1.51$ & $36.72-43.65$ & - & - & - & - & - & - \\
\hline \multicolumn{9}{|c|}{ - } \\
\hline Preflexion & $16.97 \pm 1.69$ & $12.99-20.75$ & $15.36 \pm 0.84$ & $14.03-17.10$ & $21.18 \pm 1.33$ & $19.28-23.31$ & $19.47 \pm 1.28$ & $16.03-21.90$ \\
\hline Flexion & $20.79 \pm 2.30$ & $16.68-25.71$ & $19.15 \pm 1.36$ & $17.24-21.74$ & $24.77 \pm 2.33$ & $18.59-29.42$ & $26.11 \pm 6.29$ & $19.14-37.31$ \\
\hline Postflexion & $29.21 \pm 2.15$ & $25.36-36.32$ & $30.36 \pm 3.54$ & $21.70-34.46$ & $28.10 \pm 1.33$ & $25.23-30.02$ & $31.4 \pm 2.27$ & $26.11-35.59$ \\
\hline Juvenile & $38.98 \pm 1.45$ & $35.99-41.97$ & - & - & - & - & - & - \\
\hline \multicolumn{9}{|c|}{ 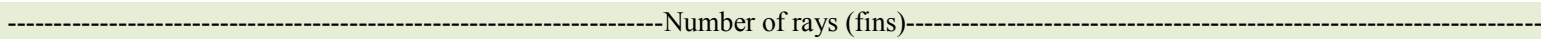 } \\
\hline Preflexion & \multicolumn{2}{|c|}{ - } & \multicolumn{2}{|c|}{-} & \multicolumn{2}{|c|}{ CF 11} & \multicolumn{2}{|c|}{ 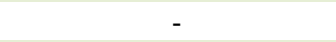 } \\
\hline Flexion & \multicolumn{2}{|c|}{ CF 6-19; DF 6-8; AF 2-6 } & \multicolumn{2}{|c|}{ - } & \multicolumn{2}{|c|}{$\begin{array}{c}\text { CF 18-20; DF 7-11; AF } \\
10-11\end{array}$} & \multicolumn{2}{|c|}{-} \\
\hline Postflexion & \multicolumn{2}{|c|}{$\begin{array}{l}\text { CF 18-19; DF 9-11; AF 7- } \\
\text { 11; PLF 0-9; PF 0-14 }\end{array}$} & \multicolumn{2}{|c|}{ - } & \multicolumn{2}{|c|}{$\begin{array}{l}\text { CF. 20-28; DF 11-12; AF } \\
\text { 11-12; PLF 3-5 }\end{array}$} & \multicolumn{2}{|c|}{ - } \\
\hline Juvenile $^{3}$ & \multicolumn{2}{|c|}{$\begin{array}{l}\text { CF 19; DF 11; AF 11; PLF } \\
8-9 ; \text { PF. } 15\end{array}$} & \multicolumn{2}{|c|}{$\begin{array}{l}\text { CF 19; DF 13; AF 10-11; } \\
\text { PLF 8-9; PF 14-17 }\end{array}$} & \multicolumn{2}{|c|}{$\begin{array}{l}\text { CF 19; DF 12-13; AF 10- } \\
\text { 12; PLF 9-10; PF. 13-16 }\end{array}$} & \multicolumn{2}{|c|}{$\begin{array}{c}\text { CF 19; DF 12-14; AF 10-12; } \\
\text { PLF 9; PF 14-16 }\end{array}$} \\
\hline
\end{tabular}

${ }^{1}$ Morphometric data from NAKATANI et al. (2001).

${ }^{2}$ Morphometric data from SOUZA et al. (2015).

${ }^{3}$ Number of fin rays of juvenile stage of $\boldsymbol{P}$. costatus, $\boldsymbol{P}$. vimboides, and $\boldsymbol{P}$. brevis obtained from CASTRO \& VARI (2004).

and $\left.045^{\circ} 15^{\prime} 7.89^{\prime \prime} \mathrm{W}\right)$ and Sub-middle São Francisco River (Paulo Afonso-BA, 09²2'49.20's and $\left.038^{\circ} 13^{\prime} 0.18^{\prime \prime} \mathrm{W}\right)$. This probably occurred due to differences between the broodstock populations used, environmental characteristics, and physical separation of the river by hydroelectric dams. In addition, water quality parameters such as temperature, $\mathrm{pH}$, and dissolved oxygen of the nursery and ponds where larvae and juveniles develop can influence their morphology. Therefore, these intraspecific morphometric differences may occur due to environmental and biological pressures to which populations are exposed during their development (LEARY et al., 1992; WIMBERGER, 1992; MATTHEWS, 1998; SOUZA JÚNIOR et al., 2002; SHIBATTA \& OHARA, 2007; MACHADO \& FORESTI, 2012). In addition, the latitudinal difference in the environmental temperature can influence the threshold size and the duration of each developmental stage among geographically isolated population of a single fish species (TAKAHASHI et al., 2012; McLEOD et al., 2015).
The changes in the body proportions over the initial development of $\boldsymbol{P}$. argenteus until stabilization depended on the morphometric characteristic considered. The increase or reduction of the body proportions occurred due to allometric differences between measurements. The initial difference in the increasing ratio of morphometric measurements is a common feature in Teleostei and is associated with evolutionary strategies such as the prioritization of the development of the body structures for feeding and swimming (FUIMAN, 1983; OSSE et al., 1997; KOVÁČ et al., 1999).

Ontogenetic shifts in the habitat use are usually associated to changes in the morphometric proportions of structures related to feeding, swimming speed and movement maneuverability such as mouth position and gap size, the position of unpaired and paired fins and its development degree (ABELHA et al., 2001; MACHADO-EVANGELISTA et al. 2016). This seems to be the case of $\boldsymbol{P}$. argenteus and possibly of other Prochilodus species that change 
from a zooplanktophagous to an iliophagous feeding habit with the concomitant change from a pelagic to a benthonic behavior. In the experimental ponds preflexion and flexion $\boldsymbol{P}$. argenteus larvae fed mainly on pelagic zooplankton (rotifers and cladocerans) even though from the postflexion stage onwards algae and particulate organic matter were the predominant items reported in the digestive tract (unpublished data).

\section{BIOETHICS AND BIOSSECURITY COMMITTEE APPROVAL}

The authors of the article entitled "Morphological development of larvae and juveniles of Prochilodus argenteus" declare, for all due purposes, that the project that gave rise to the present data has not been submitted for evaluation to the Ethics Committee of the Companhia de Desenvolvimento dos Vales do São Francisco e Parnaíba. However, they are aware of the content of the Brazilian resolutions of the Conselho Nacional de Controle de Experimentação Animal (CONCEA) $<$ http://www.mct.gov.br/index.php/content/view/310553. html $>$ involving the use of animals in experimentation. Thus, the authors assume full responsibility for the presented data and are available for possible questions, if required by the competent authorities.

\section{REFERENCES}

ABDO, T. F. et al. Initial development of Prochilodus hartii (Pisces: Prochilodontidae) submitted to induced reproduction. Zygote, v.24, n.3, p.408-417, 2016. Available from: <http:// journals.cambridge.org/action/displayAbstract?fromPage $=$ onlin e\&aid=9875596\&fileId=S0967199415000337>. Accessed: Dec. 15, 2015. doi: 10.1017/S0967199415000337.

ABELHA, M. C. F. et al. Plasticidade trófica em peixes de água doce. Acta Scientiarum Biological Sciences, v.23, p.425-434, 2008. Available from: <http://periodicos.uem.br/ojs/index.php/ ActaSciBiolSci/article/view/2696>. Accessed: Jul. 22, 2016. doi: 10.4025/actascibiolsci.v23i0.2696.

ARIAS-GALLO, M. et al. Desarrollo larval de Prochilodus magdalenae (Steindachner, 1879) (Pisces: Prochilodontidae), río Magdalena, Colombia. Actualidades Biológicas, v.32, n.93, p.199-208, 2010. Available from: <http://www.scielo.org.co/ scielo.php?pid=S0304-35842010000200007\&script=sci_arttext $>$. Accessed: Nov. 11, 2015.

BRASIL. Ministério da Pesca e Aquicultura. Boletim estatístico da pesca e aquicultura 2011. Brasília, 2013. 60p. Available from: $<$ http://www.mpa gov.br/files/docs/Boletim_MPA_2011_pub.pdf $>$. Accessed: Nov. 09, 2015.

CASTRO, R. M. C.; VARI, R. P. Family Prochilodontidae (Fannel mouth characiforms). In: REIS, R.E. et al. Checklist of the freshwater fishes of South and Central America. Porto Alegre: EDIPUCRS, 2003. p.65-70.

CASTRO, R.; VARI, R. P. Detritivores of the South American fish family Prochilodontidae (Teleostei: Ostariophysi: Characiformes): a phylogenetic and revisionary study. Smithsonian Contributions to Zoology, v.622, p.1189, 2004. Available from: $<$ http://www.sil.si.edu/smithsoniancontributions zoology/pdf_hi/SCTZ-0622.pdf>.Accessed: Nov. 10, 2015.
CAVICCHIOLI, M.; LEONHARDT, J. H. Estudo do desenvolvimento morfológico de larvas de curimbatá, Prochilodus scrofa (Steindachner, 1882), obtidas de reprodução induzida. Revista Unimar, v.15, supl, p.109-124, 1993.

FUIMAN, L. A. Growth gradients in fish larvae. Journal of Fish Biology, v.23, n.1, p.117-123, 1983. Available from: <http:// onlinelibrary.wiley.com/doi/10.1111/j.1095-8649.1983.tb02886.x/full>. Accessed: Dec. 8, 2015. doi: 10.1111/j.1095-8649.1983.tb02886.x.

KENDALL, A. W. JR. et al. Early life history stages of fishes and their characters. In: MOSER, H.G. et al. Ontogeny and systematics of fishes. Lawrence: American Society of Ichthyologists and Herpetologists, 1984. p.11-22.

KOVÁČ, V. et al. Morphometry of the stone loach, Barbatula barbatula: do mensural characters reflect the species' life history thresholds? Environmental Biology of Fishes, v.56, n.1-2, p.105-115, 1999. Available from: <http://link.springer. com/chapter/10.1007\%2F978-94-017-3678-7_8>. Accessed: Nov. 5, 2015. doi: 10.1023/A:1007570716690.

LEARY, R. F. et al. Genetic, environmental, and developmental causes of meristic variation in rainbow trout. Acta Zoologica Fennica, v.191, p.79-95, 1992.

LEIS, J. M.; TRNSKI, T. The larvae of Indo-Pacific shorefishes. Honolulu: University of Hawaii, 1989. 371p.

LEÓN, J. et al. Desarrollo embrionario y larval del bocachico Prochilodus reticulatus (Valenciennes 1849) (Cypriniformes: Prochilodontidae). Boletín del Centro de Investigaciones Biológicas, v.27,n.1,p.1-18, 1993. Available from: <http://produccioncientificaluz. org/index.php/boletin/article/view/344>. Accessed: Dec. 15, 2015

MACHADO, M. R. F.; FORESTI, F. Morphometric characteristics of Prochilodus lineatus (Valenciennes 1847), of the migratory and resident stocks of the river Mogí-Guaçu, São Paulo State, Brazil. Acta Scientiarum. Animal Sciences, v.34, n.4, p.341346, 2012. Available from: <http://periodicos.uem.br/ojs/index. php/ActaSciAnimSci/article/view/14445/pdf>. Accessed: Nov. 11, 2015. doi: 10.4025/actascianimsci.v34i4.14445.

MACHADO-EVANGELISTA, M. et al. Diet and ecomorphology of Leporinus reticulatus (Characiformes: Anostomidae) from the upper Rio Juruena, MT, Brazil: ontogenetic shifts related to the feeding ecology. Acta Amazonica, v.45, n.4, p.383-392, 2015. Available from: $<$ http://www.scielo.br/pdf/aa/v45n4/1809-4392-aa-45-04-00383. pdf $>$. Accessed: Jul. 21, 2016. doi: 10.1590/1809-4392201500551.

MATTHEWS, W. J. Patterns in freshwater fish ecology. London: Chapman and Hall, 1998. 756p.

McLEOD I. M. et al. Latitudinal variation in larval development of coral reef fishes: implications of a warming ocean. Marine Ecology Progress Series, v.521, p.129-141, 2015. Available from: <http:// www.int-res.com/abstracts/meps/v521/p129-141/>. Accessed: Jul. 22, 2016. doi: 10.3354/meps11136.

NAKATANI, K. et al. Ovos e larvas de peixes de água doce: desenvolvimento e manual de identificação. Maringá: Eduem, 2001. 378p. Available from: <http://livros.nupelia.uem.br/ovos-elarvas/>. Accessed: Jan. 29, 2014.

OSSE, J. W. M. et al. Priorities during early growth of fish larvae. Aquaculture, v.155, n.1, p.249-258, 1997. Available from: <http:// 
www.sciencedirect.com/science/article/pii/S0044848697001269>. Accessed: Dec. 1, 2015. doi: 10.1016/S0044-8486(97)00126-9.

RIBEIRO-NETO, T. F. et al. Piscicultura familiar extensiva no baixo São Francisco, estado de Sergipe, Brasil. Acta of Fisheries and Aquatic Resources, v. 4, n. 1, p. 62-69, 2016. Available from: $<$ http://www.seer.ufs.br/index.php/ActaFish/article/view/3020>. Accessed: Jul. 22, 2016. doi: 10.2312/Actafish.2016.4.1.62-69.

SHIBATTA, O. A.; OHARA, W. M. Variação morfológica em populações de Tetragonopterus argenteus Cuvier, 1817 (Characiformes, Characidae) das bacias dos rios Madeira e Paraguai. Semina: Ciências Biológicas e da Saúde, v.28, n.1, p.38, 2007. Available from: <http://www.uel.br/revistas/uel/index. php/seminabio/article/view/3483>. Accessed: Nov. 17, 2015. doi: 10.5433/1679-0367.2007v28n1p3.

SOARES, E. C. et al. Ictiofauna e pesca no entorno de Penedo, Alagoas. Biotemas, v.24, n.1,p.61-67, 2011. Available from: $<$ https://periodicos. ufsc.br/index.php/biotemas/article/view/2175-7925.2011v24n1p61>. Accessed: Dec. 23, 2015. doi: 10.5007/2175-7925.2011v24n1p61.

SOUZA JÚNIOR, J. P. et al. Diversificação intra-especifica do pargo, Lutjanus purpureus Poey, no Norte e Nordeste do Brasil. I - Caracteres morfométricos. Acta Scientiarum. Animal Sciences, v.24, n.4, p.973-980, 2002. Available from: $<$ http://periodicos.uem.
br/ojs/index.php/ActaSciAnimSci/article/view/2457>. Accessed: Jan. 27, 2015. doi: 10.4025/actascianimsci.v24i0.2457.

SOUZA, G. et al. Early development and allometric growth patterns of the grumatã (Prochilodus vimboides Kner, 1859). Zygote, v.24, n.3, p.428-441, 2016. Available from: <https:// www.cambridge.org/core/journals/zygote/article/earlydevelopment-and-allometric-growth-patterns-of-the-grumataprochilodus-vimboides-kner-1859/556469877AC0CC3D61 AE964058D47E23>. Accessed: Nov. 11, 2015. doi: 10.1017/ S0967199415000350.

TAKAHASHI, M. et al. Influence of seasonal and latitudinal temperature variation on early life-history traits of a coral reef fish. Marine and Freshwater Research, v.63, p.856864, 2012. Available from: <http://www.publish.csiro. au/mf/MF11278>. Accessed: Jul. 22, 2016. doi: 10.1071/ MF11278.

WIMBERGER, P. H. Plasticity of fish body shape: the effects of diet, development, family and age in two species of Geophagus (Pisces: Cichlidae). Biological Journal of the Linnean Society, v.45, n.3, p.197-218, 1992. Available from: $<$ http://onlinelibrary.wiley.com/doi/10.1111/j.1095-8312.1992. tb00640.x/abstract>. Accessed: Nov. 17, 2015. doi: 10.1111/ j.1095-8312.1992.tb00640.x. 